\title{
Allelopathic, Phytotoxic, and Insecticidal Effects of Thymus proximus Serg. Essential Oil and Its Major Constituents
}

\author{
Shixing Zhou ${ }^{1,2}$, Caixia Han ${ }^{1}$, Chenpeng Zhang ${ }^{1,2}$, Nigora Kuchkarova ${ }^{1,3}$, Caixia Wei ${ }^{1,2}$, \\ Chi Zhang ${ }^{4 *}$ and Hua Shao ${ }^{1,2,3 *}$ \\ ${ }^{1}$ State Key Laboratory of Desert and Oasis Ecology, Xinjiang Institute of Ecology and Geography, Chinese Academy of \\ Sciences, Ürümqi, China, ${ }^{2}$ University of Chinese Academy of Sciences, Beijing, China, ${ }^{3}$ Research Center for Ecology and \\ Environment of Central Asia, Xinjiang Institute of Ecology and Geography, Chinese Academy of Sciences, Ürümqi, China, \\ ${ }^{4}$ Shandong Provincial Key Laboratory of Water and Soil Conservation and Environmental Protection, College of Resources \\ and Environment, Linyi University, Linyi, China
}

OPEN ACCESS

Edited by:

Rachid Lahlali,

Ecole Nationale d'Agriculture de

Meknès, Morocco

Reviewed by:

Asgar Ebadollahi,

University of Mohaghegh Ardabili, Iran

Harminder Pal Singh,

Panjab University, India

Dorota Jadczak,

West Pomeranian University of

Technology, Poland

*Correspondence:

Chi Zhang

zc@ms.xjb.ac.cn

Hua Shao

shaohua@ms.xjb.ac.cn

Specialty section:

This article was submitted to Plant Metabolism and Chemodiversity,

a section of the journal

Frontiers in Plant Science

Received: 01 April 2021

Accepted: 19 May 2021

Published: 15 June 2021

Citation:

Zhou S, Han C, Zhang C, Kuchkarova N, Wei C, Zhang $\mathrm{C}$ and Shao H (2021) Allelopathic, Phytotoxic, and Insecticidal Effects of

Thymus proximus Serg. Essential Oil and Its Major Constituents.

Front. Plant Sci. 12:689875.

doi: 10.3389/fpls.2021.689875
The chemical profile of Thymus proximus essential oil (EO) and its allelopathic, phytotoxic, and insecticidal activity was evaluated. Carvacrol, p-cymene, and $\gamma$-terpinene were detected as the major components of the EO, representing $85.9 \%$ of the total oil. About $50 \mathrm{~g}$ fresh plant material of $T$. proximus in a 1.5-L air tight container completely inhibited the seed germination of Amaranthus retroflexus and Poa anuua. Meanwhile, the EO exhibited potent phytotoxic activity, which resulted in $100 \%$ germination failure of both the test species when $2 \mathrm{mg} / \mathrm{ml}$ (for $A$. retroflexus) and $5 \mathrm{mg} / \mathrm{ml}$ (for Poa annua) oil was applied. The EO also triggered a significant insecticidal activity on Aphis gossypii with a LC 50 value of $6.34 \mathrm{ppm}$. Carvacrol was identified as the main active compound responsible for both the plant suppressing effect and the insecticidal activity of the EO. Our study is the first on the allelopathic, phytotoxic, and insecticidal activity of T. proximus EO, and the determination of the responsible compound, which indicated their potential of being further explored as environment friendly biopesticides.

Keywords: phytotoxicity, biopesticides, carvacrol, P-cymene, $\gamma$-terpinene

\section{INTRODUCTION}

Essential oils (EOs) are mixtures of plant-derived secondary metabolites that are extensively applied in food preservation and medical practices for thousands of years (Majewska et al., 2019; Suteu et al., 2020; Giunti et al., 2021). Many aromatic plants are known for their extraordinary ability to produce a large amount of EOs that can repel grazers, kill pests, or inhibit the growth of competing plants growing in the neighborhood (Willmer et al., 2009; Aungtikun et al., 2021; Han et al., 2021; Sousa et al., 2021). Due to these qualities, certain EOs obtained from aromatic plants, including their major constituents, have the potential to be used as environmentally compatible alternatives to synthetic pesticides and herbicides. Successful commercialized examples include clove oil, which is the main active ingredient in the herbicide Burnout II (Bonide Products Inc., Oriskany, NY, USA), and cinmethylin, the phytotoxin 1,4-cineole's derivative that can be detected in EOs of many plants (Grayson et al., 1987; Ahuja et al., 2015). On the other hand, the commercial production of pest management products based on plant EOs appears to have lagged significantly behind, indicating a major disconnect between academic research and industrial practice (Isman, 2017). 
However, there are some commercial pesticides that contain plant EOs. For example, a commercial product named as "Rice Weevil Eradication" (manufacturer: Hub Club, Siheung, Korea) containing cinnamon [Cinnamomum cassia (L.) J. Presl] oil as its active ingredient (Yang et al., 2020). Ecotrol Plus, the flagship agricultural product produced and marketed by KeyPlex Co. (Winter Park, FL, USA), introduced in 2003, contains $10 \%$ rosemary oil, $2 \%$ peppermint oil, and $5 \%$ geraniol as active ingredients.

Worldwide, synthetic chemicals are used in agriculture; however, the extensive application has triggered resistance in pests, not to mention that they can cause many problems not only to the environment but also to human health. Compared to synthetic chemicals, plant-derived natural compounds have the advantages of fast biodegradability, low risk for subsequent pest/weed resistance, and relatively weak toxicity to non-target organisms (Chandler et al., 2011; Isman, 2015; Pavela and Benelli, 2016).

To the best of our knowledge, environment friendly agricultural chemicals are particularly important to drylands, which are characteristic for low precipitation and simple, fragile soil microbiota, which almost unavoidably cause slow degradation rate of synthetic chemicals; the accumulation of synthetic compounds subsequently might result in acute and chronic toxicity to human and herds and pose threat on the environment such as suppressing the growth of desert plants, which lead to increased wind soil erosion (Pavela, 2015). Due to the occurrence of resistance of agricultural pests to synthetic chemicals, farmers have to either increase the amount of application or switch to a new type of pesticides and herbicides, which may considerably increase the costs of maintaining dryland farms (Benhalima et al., 2004; Ahmad and Jaiswal, 2015). In addition, dryland harbors very rich natural resource of medicinal aromatic plants. Many desert aromatic plants belonging to the genus Thymus are known for their outstanding ability to produce high productivity and quality of EOs, which have been widely used in pharmaceutical, food, and cosmetic applications (Stahl-Biskup and Saez, 2002; Imelouane et al., 2009). Thymus proximus Serg, for example, a dense and robust shrub distributes over a wide range of mountainous regions and predominantly scatters in northwest China and Central Asia dryland ( $\mathrm{Wu}$ et al., 1983), was found to have antimicrobial, antioxidant, and other biological activities (Jia et al., 2010). T. proximus is known for its high productivity of EOs, and like reports on some other desert aromatic plants including Thymus species growing in the drylands, its EO might have the allelopathic effect that can either act directly as volatile allelochemicals or accumulate in the soil to impact the growth of neighboring plants (Barney et al., 2009; Inderjit et al., 2011; Ali et al., 2014, 2015; Alexa et al., 2018; Vaiciulyte and Loziene, 2020).

Although some biological activities, such as antimicrobial activity of $T$. proximus $\mathrm{EO}$, have been reported before, its allelopathic, phytotoxic, and insecticidal activities are not studied, and the bioactive compound(s) remains unclear. The objectives of our study include: (i) evaluation of the phytochemical profile of the EO produced by the desert plant $T$. proximus growing in Xinjiang province of China; (ii) assessment of the allelopathic, phytotoxic, and pesticidal effects of the EO and its major components; and (iii) determination of the major active component responsible for the biological activities of the EO.

\section{MATERIALS AND METHODS}

\section{Plant Material}

Aboveground T. proximus Serg. material (flowering shoot) was collected in Tianshan mountains (Lat $43.4268^{\circ} \mathrm{N}$, Lon $87.1764^{\circ} \mathrm{E}$, with an elevation of 2,006 m) in Xinjiang Province, China in June, 2019. Specimens were identified by Professor Li Wenjun, and a voucher specimen (XJBI018367) was deposited at the Xinjiang Institute of Ecology and Geography, Chinese Academy of Sciences Ownbey Herbarium.

\section{Extraction of the EO}

About $200 \mathrm{~g}$ of fresh materials of $T$. proximus was hydrodistillated for $4 \mathrm{~h}$ using a Clevenger-type apparatus to extract the EO, and this procedure was repeated three times (altogether $600 \mathrm{~g}$ plant material was used) to yield enough oil for the gas chromatography/mass spectroscopy (GC/MS) analysis and the following bioassay. The oil was then dried using anhydrous $\mathrm{Na}_{2} \mathrm{SO}_{4}$ and kept at $4^{\circ} \mathrm{C}$.

\section{GC/MS Analysis}

The GC/MS analysis was performed to determine the chemical profile of T. proximus EO using a 7890A/5975C GC/MS system (Agilent Technologies, Palo Alto, CA, USA) equipped with a (5\%-phenyl)-methylpolysiloxane phase column $(30 \mathrm{~m}$ $\times 0.25 \mathrm{~mm}$; film thickness $0.25 \mu \mathrm{m}$ ), DB-5MS (Agilent $\mathrm{J} \& \mathrm{~W}$ Scientific, Folsom, CA, USA). The experimental conditions were programmed as follows: Helium (carrier gas) at a flow rate of 1 $\mathrm{ml} / \mathrm{min}$; the oven temperature was first held at $50^{\circ} \mathrm{C}$ for $10 \mathrm{~min}$ and then programmed from 50 to $120^{\circ} \mathrm{C}$ at a rate of $1.5^{\circ} \mathrm{C} / \mathrm{min}$ and from 120 to $240^{\circ} \mathrm{C}$ at $20^{\circ} \mathrm{C} / \mathrm{min}$ and then held for $5 \mathrm{~min}$; injector and detector temperature: $280^{\circ} \mathrm{C}$; sample volume: $0.1 \mu \mathrm{l}$; split ratio: 50:1; mass spectra: $70 \mathrm{eV}$, mass range: $m / z 40-800 \mathrm{amu}$. Identification of the compounds was determined by comparison of their mass spectra and retention indices (RIs), which were determined by the linear interpolation relative to retention times of a standard mixture of $\mathrm{C}_{7}-\mathrm{C}_{40} n$-alkanes with the data given in National Institute of Standards and Technology (NIST) and published literature (Oladipupo and Adebola, 2009; Shao et al., 2018).

\section{Allelopathic Effect}

Fresh stems and leaves of $T$. proximus were arranged into plastic containers $(13.5 \times 13.5 \times 8.5 \mathrm{~cm}$, volume $1.5 \mathrm{~L})$ at the following ratios: $0 \mathrm{~g}, 6.67 \mathrm{~g}, 13.33 \mathrm{~g}$, and $26.67 \mathrm{~g} / \mathrm{L}$ containers. Their allelopathic potential was assessed by performing bioassays against Amaranthus retroflexus L. and Poa annua L., which grow in the same habitat alongside $T$. proximus. Seeds of receiver species were surface sterilized with $2 \%$ sodium hypochlorite before use. Distilled $\mathrm{H}_{2} \mathrm{O}(5 \mathrm{ml})$ was added to each Petri dish $(\phi$ $9 \mathrm{~cm}$, lined with a layer of filter paper), followed by sowing of 20 seeds. Each container received one Petri dish that was placed onto 
the plant material. Containers without plant materials $(0 \mathrm{~g})$ were used as the control. All containers were kept open for 5 min each day to allow in the fresh air. A. retroflexus and $P$. annua seedlings were measured after 5 and 7 days of incubation, respectively, due to relatively slow development of $P$. annua seedlings. Three replicates were prepared for the bioassay and in total 50 seedlings were measured (Williamson and Richardson, 1988; Wei et al., 2019; $n=50)$.

\section{Phytotoxic Effect of the EO and Its Major Components}

Amaranthus retroflexus and $P$. annua were used to evaluate the phytotoxic activity of the $\mathrm{EO}$ and its major ingredients. pCymene, $\gamma$-terpinene, and carvacrol (purity 98\%) were purchased from Sigma-Aldrich Co. (St. Louis, MO, USA). Seeds of the test species were surface sterilized with $2 \%$ sodium hypochlorite before application of the oil and its major components. $T$. proximus oil and the major components were first dissolved in dimethyl sulfoxide (DMSO, $0.1 \% \mathrm{v} / \mathrm{v}$ final concentration) and then diluted with the distilled water containing Tween 80 (final concentration $0.02 \%$ ) to yield solutions at $0.25,0.5,1$, 2, 5, and $10 \mathrm{mg} / \mathrm{ml}$ for the assay. Previously, DMSO has been adopted in similar bioassays due to the fact that essential oils and oil constituents are soluble in it, and that DMSO does not pose significant inhibitory effect on test plants (Tanveer et al., 2012; Pinto et al., 2015). The mixture of the three major constituents was prepared by combining p-cymene, $\gamma$-terpinene, and carvacrol at the ratio of 44.3:33.2:8.5, which was identical to their relative percentage in the $\mathrm{EO}$ to test their possible synergistic/antagonistic effect.

About $5 \mathrm{ml}$ of solutions were added to each Petri dish $(\phi 9 \mathrm{~cm}$; controls received $5 \mathrm{ml}$ of distilled $\mathrm{H}_{2} \mathrm{O}$ containing $0.1 \%$ DMSO and $0.02 \%$ Tween 80 ), followed by sowing of 10 test seeds. Petri dishes were sealed with parafilm and kept in a growth cabinet at $25^{\circ} \mathrm{C}$ with a photoperiod $\mathrm{L}: \mathrm{D}=16: 8$. A. retroflexus and $P$. annua seedlings were checked and measured after 5 and 7 days of incubation, respectively, due to relative slow development of $P$. annua seedlings. Five replicates were performed for the assays, and in total 50 seedlings were measured ( $n=50$; Shao et al., 2018).

\section{Insecticidal Activity of the EO}

Thymus proximus oil, $\mathrm{p}$-cymene, $\boldsymbol{\gamma}$-terpinene, carvacrol and their mixture (ratio of $44.3: 33.2: 8.5$, the relative percentage in the EO) at $2.5,5,10,20,50$, and $100 \mathrm{ppm}$ was impregnated into the Whatman No.2 filter paper (Maidstone, Kent, United Kingdom) discs $(1 \times 1 \mathrm{~cm})$, which were then taped onto the inner side of the lid of each Petri dishes $(9 \mathrm{~cm}$ in diameter) to avoid direct contact between the EO/major components and Aphis gossypii Glover. Thirty adults of A. gossypii were placed onto a healthy fresh black nightshade (Solanum nigrum) leaf on a layer of moist filter paper. All Petri dishes were covered and kept in an incubator (25 $\pm 2{ }^{\circ} \mathrm{C}$, photoperiod L:D $=16: 8$ ) for 2 days. Mortalities of the adults were determined at $24-\mathrm{h}$ intervals after treatment. Three replicates were performed to measure the insecticidal activity, which was expressed as percent mean mortalities of the adult $A$. gossip (Laborda et al., 2013; Zhou et al., 2019).

\section{Statistical Analyses}

The bioassay experiment followed a completely randomized design with five replications and 50 seedlings for each treatment. Results were expressed as mean $\pm \mathrm{SE}$ of the mean. One-way ANOVA $(p<0.05)$ was applied using the IBM SPSS statistical package version 21.0 (IBM SPSS, Armonk, NY, USA) for Windows to examine whether the difference of the allelopathic, phytotoxic, and insecticidal effects of the EO produced by T. proximus, their major constituents, that is, p-cymene, $\gamma$ terpinene, and carvacrol and their mixture tested at different concentrations was significant; then all data were further processed using the Fisher's least significant difference (LSD) test at $p<0.05$ level to compare the difference among treatments. The inhibitory concentration required for $50 \%$ inhibition $\left(\mathrm{IC}_{50} / \mathrm{LC}_{50}\right)$ values were calculated using the PROBIT analysis (SAS/STAT User's Guide; SAS Institute Inc., Cary, NC, USA).

\section{RESULTS}

\section{Essential Oil Yield and Composition}

The EO of $T$. proximus was obtained by the traditional hydrodistillation method using fresh aboveground plant materials. The yield was $0.35 \%$ (v/w, volume/fresh weight). Eventually, 18 compounds were determined, which accounted for $98.51 \%$ of the total oil, whereas $1.49 \%$ of the oil remained unclassified. The most abundant components were p-cymene (44.26\%), $\gamma$-terpinene (33.17\%), and carvacrol (8.47\%), which represented $85.9 \%$ of the total oil. Monoterpene hydrocarbons accounted for $86.60 \%$ of the total oil, whereas oxygenated monoterpenes and sesquiterpene hydrocarbons represented 10.05 and $1.86 \%$ of the total oil, respectively (Table $\mathbf{1}$ ).

\section{Allelopathic Potential}

The allelopathic effect of volatile organic compounds (VOCs) released by $T$. proximus was investigated by arranging fresh aboveground plant parts into air-tight plastic containers; $A$. retroflexus (dicot) and $P$. anuua (monocot), which are found growing in the same habitat alongside $T$. proximus, were selected as the test species VOCs released by $T$. proximus at $6.67 \mathrm{~g} / \mathrm{L}$ containers suppressed radical elongation of $A$. retroflexus and $P$. anuua by 40.1 and $31.1 \%$, respectively, and $13.33 \mathrm{~g} / \mathrm{L}$ treatment resulted in the reduction of the root elongation by 48.8 and 63.6\% for A. retroflexus and P. anuua, respectively. About 26.67 $\mathrm{g} / \mathrm{L}$ treatment basically prohibited the seed germination of two test species. $P$. annua (monocot) was apparently more sensitive compared to $A$. retroflexus (dicot); the $\mathrm{IC}_{50}$ values were 14.69 and $14.42 \mathrm{~g}$ for A. retroflexus and P. annua roots, and 20.595 and $16.316 \mathrm{~g}$ for shoots, respectively (Figure 1).

\section{Phytotoxic Activity Bioassay}

Phytotoxic activity of the EO (concentrations applied ranging from 0.25 to $5 \mathrm{mg} / \mathrm{ml}$ ) and its major components was assessed by comparing their plant regulatory effect on the seedling growth of $A$. retroflexus and $P$. annua. For $A$. retroflexus, p-cymene promoted the root development of $A$. retroflexus at $0.5 \mathrm{mg} / \mathrm{ml}$; however, the inhibitory activity was observed with the increase of concentration, and $5 \mathrm{mg} / \mathrm{ml}$ treatment resulted in $93.54 \%$ 
TABLE 1 | Chemical composition of Thymus proximus essential oil.

\begin{tabular}{|c|c|c|c|c|}
\hline Compounds & $\mathbf{R} \mathbf{l}^{\mathbf{a}}$ & $\mathbf{R} \mathbf{I}^{\mathbf{b}}$ & Area (\%) & Identification \\
\hline$\alpha$-Thujene & 913 & 924 & 1.76 & $\mathrm{MS}, \mathrm{RI}$ \\
\hline$\alpha$-Pinene & 928 & $938^{*}$ & 0.93 & MS, RI \\
\hline (-)-Camphene & 946 & 952 & 0.66 & MS, RI \\
\hline 4-Thujene & 965 & 969 & 0.3 & MS, RI \\
\hline$\beta$-Pinene & 976 & 982 & 1.41 & MS, RI \\
\hline$\delta$-Carene & 1,006 & 1,004 & 2.52 & MS, RI \\
\hline p-Cymene & 1,011 & 1,012 & 44.26 & MS, RI \\
\hline 1,5-Dimethyl cyclooctadiene & 1,018 & 1,017 & 0.49 & MS, RI \\
\hline$\beta$-(Z)-Ocimene & 1,038 & 1,041 & 0.63 & MS, RI \\
\hline$\gamma$-Terpinene & 1,047 & 1,056 & 33.17 & $\mathrm{MS}, \mathrm{RI}$ \\
\hline Terpinolene & 1,050 & 1,084 & 0.47 & MS, RI \\
\hline Borneol & 1,142 & 1,173 & 0.61 & $\mathrm{MS}, \mathrm{Rl}$ \\
\hline Carvacrol & 1,273 & 1,287 & 8.47 & MS, RI \\
\hline 2-Ethyl-4,5-dimethylphenol & 1,281 & 1,300 & 0.53 & MS, RI \\
\hline Thymol & 1,284 & 1,287 & 0.05 & MS, Rl \\
\hline Durenol & 1,324 & 1,319 & 0.39 & $\mathrm{MS}, \mathrm{Rl}$ \\
\hline Caryophyllene & 1,401 & 1,415 & 1.08 & MS, RI \\
\hline$\beta$-Bisabolene & 1,495 & 1,489 & 0.78 & MS, RI \\
\hline Monoterpene hydrocarbons & & & 86.6 & \\
\hline Oxygenated monoterpenes & & & 10.05 & \\
\hline Sesquiterpene hydrocarbons & & & 1.86 & \\
\hline Total identified & & & 98.51 & \\
\hline
\end{tabular}

$R^{a}$, Retention index measured relative to $n$-alkanes $\left(C_{7}-C_{40}\right)$ using a DB-5MS column; $R l^{b}$, Retention index from literature; MS, mass spectra.

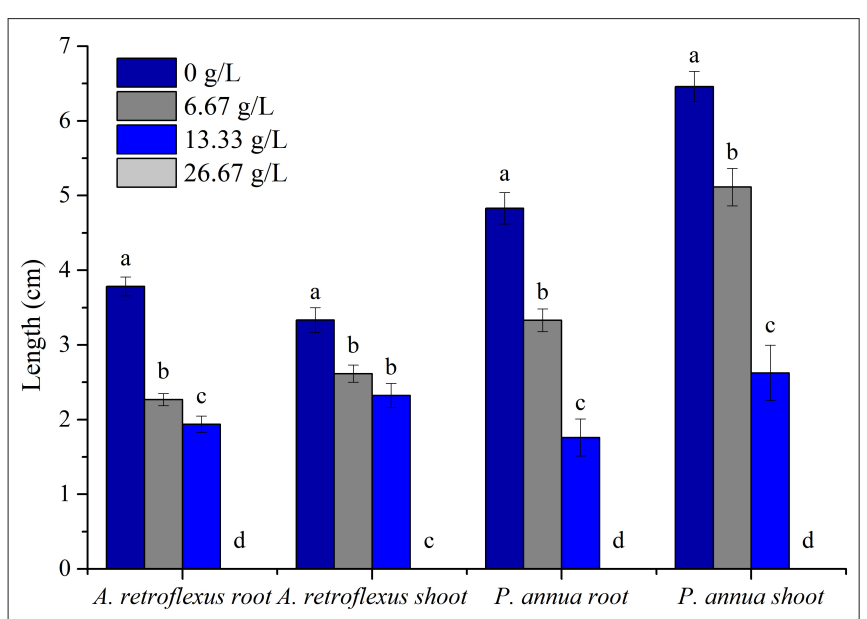

FIGURE 1 | Allelopathic effect of volatile organic compounds (VOCs) released by Thymus proximus on the root and shoot elongation of Amaranthus retroflexus and Poa annua. Means with different letters indicate significant differences at $p<0.05$ level according to the Fisher's least significant difference (LSD) test.

reduction on the root development. $\gamma$-Terpinene exhibited relatively stronger activity against $A$. retroflexus, inhibiting the root length by $52.35 \%$ at $2 \mathrm{mg} / \mathrm{ml}$, and $89.55 \%$ at $5 \mathrm{mg} / \mathrm{ml}$. The third major constituent, carvacrol, showed remarkably stronger activity compared with the other two compounds, which completely suppressed the seed germination at the lowest concentration tested $(0.25 \mathrm{mg} / \mathrm{ml})$. The mixture of these three major components exhibited stronger activity than p-cymene and $\gamma$-terpinene but much weaker activity than carvacrol, which reduced the root length by $33.92 \%$ at $0.5 \mathrm{mg} / \mathrm{ml}$, and $98.94 \%$ at $1 \mathrm{mg} / \mathrm{ml}$. When the concentration reached $2 \mathrm{mg} / \mathrm{ml}$, the seed development was completely prohibited. In conclusion, the EO exerted more potent activity than p-cymene and $\gamma$-terpinene but much weaker activity than carvacrol; the strength of the EO was comparable but still somewhat weaker than the mixture; the $\mathrm{IC}_{50}$ values of p-cymene, $\gamma$-terpinene, mixture, and the EO were 4.52, $3.78,2.06$, and $2.60 \mathrm{mg} / \mathrm{ml}$, respectively (Figure 2, Table 2).

Similarly, for the monocot plant $P$. annua, carvacrol exhibited the most potent activity, which completely suppressed its seed germination at $0.25 \mathrm{mg} / \mathrm{ml}$, the lowest concentration applied in the assay. The EO exhibited comparable activity compared with $\mathrm{p}$-cymene and $\gamma$-terpinene, whose $\mathrm{IC}_{50}$ values were $3.65,3.89$, and $3.63 \mathrm{mg} / \mathrm{ml}$, respectively, and the mixture showed much stronger activity with the $\mathrm{IC}_{50}$ value of $1.62 \mathrm{mg} / \mathrm{ml}$ (Figure 2, Table 2).

However, the seedling growth exhibited a similar pattern as the root development to a lesser extent. Carvacrol caused complete failure of the seed development of $P$. annua and A. retroflexus at the lowest concentration tested $(0.25 \mathrm{mg} / \mathrm{ml})$, whereas the other components and EO started to inhibit shoot growth of $A$. retroflexus at $0.25 \mathrm{mg} / \mathrm{ml}$ as well, representing 13.32 , $20.37,23.02$, and $35.36 \%$ for p-cymene, $\gamma$-terpinene, a mixture of main components, and EO, respectively. When the concentration 

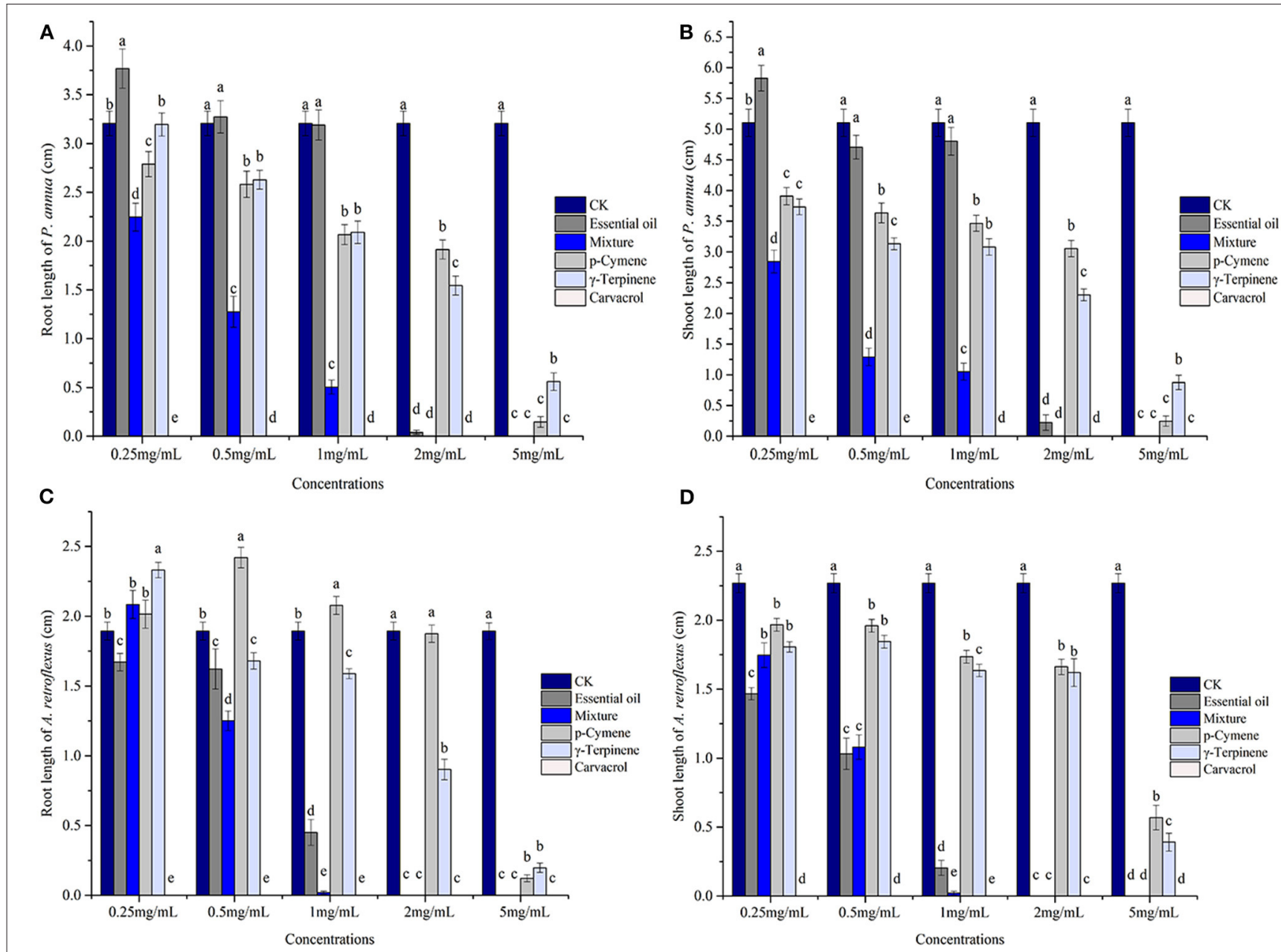

D

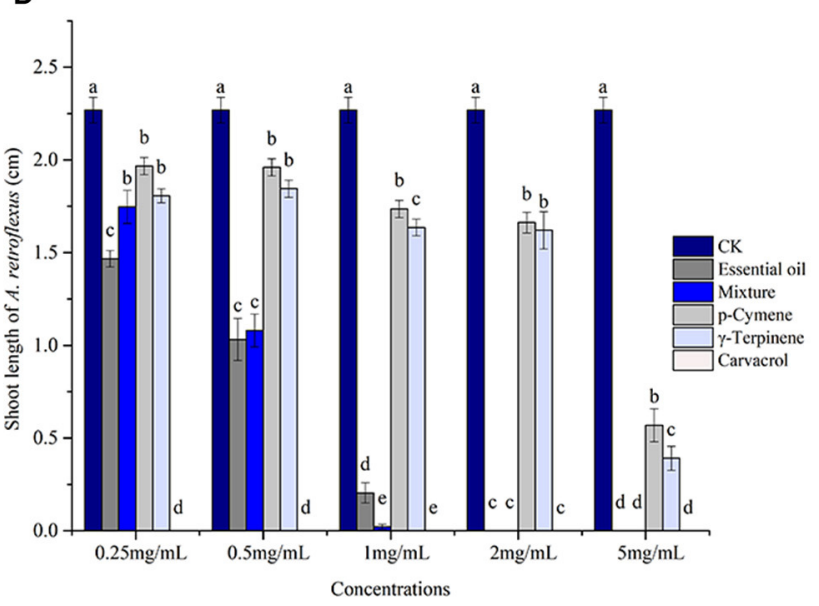

FIGURE 2 | Phytotoxic effects of Thymus proximus essential oil (EO) and its major constituents, p-cymene, $\gamma$-terpinene, carvacrol, and their mixture on the seedling growth of Poa annua and Amaranthus retroflexus $(n=50)$. Different letters represent a significant difference at $p<0.05$ level according to the Fisher's LSD test. (A) root length of $P$. annua; (B) shoot length of $P$. annua; (C) root length of $A$. retroflexus; and (D) shoot length of $A$. retroflexus.

raised to $5 \mathrm{mg} / \mathrm{ml}$, the $\mathrm{EO}$ and mixture of major ingredients completely inhibited the shoot growth, while p-cymene and $\gamma$ terpinene suppressing the shoot growth of $A$. retroflexus by 74.93 and $82.76 \%$, respectively. The effect of $P$. annua is similar to $A$. retroflexus, with $\mathrm{IC}_{50}$ values of $3.93,3.55,0.83$, and $3.35 \mathrm{mg} / \mathrm{ml}$ for $\mathrm{p}$-cymene, $\gamma$-terpinene, and mixture of principal components and EO, respectively (Figure 2, Table 2). The dose-response curve of the phytotoxic activity was shown in Figure 3.

\section{Insecticidal Activity}

The insecticidal activity of $T$. proximus EO was determined on adjusted mortality rates of $A$. gossypii at concentrations ranging from 2.5 to $100 \mathrm{ppm}$. Results showed that T. proximus EO had obvious behavioral avoidance and lethal action on A. gossypii. The EO, its major components, and their mixture killed all the tested insects at the dose of $100 \mathrm{ppm}$ after $24 \mathrm{~h}$ of exposure. The mortality rates of $T$. proximus under $2.5,5,10,20$, and $50 \mathrm{ppm}$, the EO treatments reached $15,15.33,40.67,93.33$, and $99.00 \%$, respectively, after $24 \mathrm{~h}$ of exposure to the oil. Carvacrol showed the strongest activity against $A$. gossypii with a $\mathrm{LC}_{50}$ value of 0.1 ppm, compared with the $\mathrm{LC}_{50}$ values of $9.63,5.69,6.8$, and 7.34 ppm for the EO, p-cymene, $\gamma$-terpinene, and the mixture of three major components, respectively (Table 3 ). The dose-response curve of the pesticidal activity was shown in Figure 4.

\section{DISCUSSION}

A large body of literature has reported the chemical composition of the EOs produced by Thymus species, which were frequently found to have abundant thymol, carvacrol, p-cymene, $\gamma$ terpinene, caryophyllene oxide, etc. (Kabouche et al., 2005; Hazzit et al., 2006; Sanja and Milka, 2015; Zeynep et al.,, 2018; Behnaz et al., 2020). Marla et al. (2008) investigated the chemical composition of T. vulgaris $\mathrm{EO}$ and found it was rich in thymol (57.7\%), p-cymene (18.7\%), and carvacrol (2.8\%). Behnaz et al. (2017) evaluated the EOs produced by14 Thymus accessions belonging to 10 species and found that their major components were thymol (12.4-79.74\%), carvacrol (4.37-42.14\%), geraniol 
TABLE 2 | Regression analyses of the phytotoxic effect of Thymus proximus essential oil (EO), its major constituents p-cymene, $\gamma$-terpinene, and carvacrol, and their mixture on the root and shoot growth of Amaranthus retroflexus and Poa annua.

\begin{tabular}{|c|c|c|c|c|c|}
\hline Test plants & EO/major components & Regression equation & $r^{2}$ & $\mathrm{IC}_{50}(\mathrm{mg} / \mathrm{ml})$ & $95 \% \mathrm{CL}$ \\
\hline \multirow[t]{5}{*}{ A. retroflexus root } & p-Cymene & $y=15.753 x^{2}-71.642 x+51.737$ & 0.951 & 4.52 & $3.93-5.11$ \\
\hline & $\gamma$-Terpinene & $y=26.643 x-50.704$ & 0.958 & 3.78 & $3.25-4.31$ \\
\hline & Carvacrol & - & - & - & - \\
\hline & Mixture & $y=-10.857 x^{2}+93.768 x-97.324$ & 0.965 & 2.06 & $1.48-2.64$ \\
\hline & Essential oil & $y=26.221 x-18.216$ & 0.873 & 2.60 & $2.05-3.15$ \\
\hline \multirow[t]{5}{*}{ A. retroflexus shoot } & p-Cymene & $y=6.3663 x^{2}-24.564 x+34.084$ & 0.927 & 3.03 & $2.71-3.35$ \\
\hline & $\gamma$-Terpinene & $y=7.3667 x^{2}-30.733 x+46.836$ & 0.903 & 4.27 & $3.94-4.60$ \\
\hline & Carvacrol & - & - & - & - \\
\hline & Mixture & $y=-7.4577 x^{2}+64.903 x-37.786$ & 0.961 & 1.67 & $1.23-2.11$ \\
\hline & Essential oil & $y=-4.7013 x^{2}+45.681 x-9.1479$ & 0.964 & 1.54 & $1.17-1.91$ \\
\hline \multirow[t]{5}{*}{ P. annua root } & p-Cymene & $y=6.143 x^{2}-18.292 x+28.067$ & 0.938 & 3.89 & $3.49-4.29$ \\
\hline & $\gamma$-Terpinene & $y=19.82 x-21.954$ & 0.982 & 3.63 & $3.24-4.02$ \\
\hline & Carvacrol & - & - & - & - \\
\hline & Mixture & $y=17.99 x+20.915$ & 0.903 & 1.62 & $1.25-1.99$ \\
\hline & Essential oil & $y=4.8065 x^{2}+4.751 x-31.199$ & 0.853 & 3.65 & $2.93-4.37$ \\
\hline \multirow[t]{5}{*}{ P. annua shoot } & p-Cymene & $y=7.4384 x^{2}-29.138 x+49.486$ & 0.923 & 3.93 & $3.57-4.29$ \\
\hline & $\gamma$-Terpinene & $y=3.335 x^{2}-7.1789 x+33.397$ & 0.965 & 3.55 & $3.28-3.82$ \\
\hline & Carvacrol & - & - & - & - \\
\hline & Mixture & $y=13.68 x+38.628$ & 0.889 & 0.83 & $0.55-1.11$ \\
\hline & Essential oil & $y=31.638 x-55.906$ & 0.865 & 3.35 & $2.71-3.99$ \\
\hline
\end{tabular}

$r^{2}$ : adjusted coefficient of determination.

$1 C_{50}$ : the inhibitory concentration required for $50 \%$ inhibition.

95\% CL: 95\% confidence limits.

(-): not calculable.

(0.3-22.44\%), and p-cymene (0.8-12.86\%). As of the EO of T. proximus, Jia et al. (2010) identified 60 compounds from the EO of T. proximus, which accounted for $99 \%$ of the total oil, with p-cymene (25.4\%), $\gamma$-terpinene (18.0\%), and thymol (28.0\%) being the most abundant components, which was consistent with our results. It is noteworthy to mention that there are various factors that might affect the chemical profile of plant-derived EOs including but not limited to species variety, growth period, geographic locality, surrounding climate, stress, and post-harvest processing, etc. (Raut et al., 2014).

Many plants are capable of synthesizing and releasing VOCs that are found to play key roles in attracting seed-disperser and pollinators, defense against pathogenic fungi and herbivores, interplant signaling, and allelopathic action (Pichersky and Gershenzon, 2002; Dudareva et al., 2013; Adebesin et al., 2017). Wei et al. (2019) reported that VOCs produced by Atriplex cana Ledeb. negatively affected the seedling development of $A$. retroflexus and $P$. annua, with $80 \mathrm{~g}$ of fresh $A$. cana leaves and stems in a 1.5 - $\mathrm{L}$ airtight container almost completely prohibited the seed germination of the test plants. Volatiles emitted from the leaves of star anise (Illicium verum Hook. f.) totally inhibited the seedling growth of Lactuca sativa L., and the major volatile compounds were identified as $\alpha$-pinene, $\beta$-pinene, camphene, 1,8-cineole, D-limonene, camphor, and L-fenchone (Kang et al., 2019). Tang et al. (2019) reported the allelopathic activity of VOCs released by the exotic invasive weed Xanthium sibiricum and found that at $80 \mathrm{~g}$ fresh plant materials in a $1.5-\mathrm{L}$ airtight container, root growth of receiver plants $A$. retroflexus and $P$. annua was reduced by 49.1 and $69.6 \%$, respectively. The release of volatile allelochemicals into the surroundings are believed to be able to facilitate the dominance of the donor species; and interestingly, herbivore-infested plants are found to produce volatiles to mediate plant-plant interactions by triggering the expression of volatiles of neighboring unattacked plants to decrease their susceptibility to herbivores (Ruther and Kleier, 2005).

There have been a number of reports on the phytotoxic effects of EOs and their constituents, especially monoterpenes, on the seed germination and seedling growth of the test species (Langenheim, 1994; Vokou et al., 2003; Nishida et al., 2005; Salamci et al., 2007). EOs produced by Thymus species have also been studied for their phytotoxicity. Ali et al. (2015) found that EOs obtained from different plant parts of T. algeriensis inhibited both the shoot and root growth of Medicago sativa L. and Triticum astivum L. seedlings at the lowest tested concentration (0.1 mg/ml). T. daenensis Celak. EO significantly suppressed the seedling development of $A$. retroflexus, and $600 \mu \mathrm{l} / \mathrm{l}$ oil almost completely prohibited its seedling growth (Kashkooli and Saharkhiz, 2014). Another species of the Thymus genus, T. eigii, showed significant herbicidal activity against L. sativa, Lepidium sativum L., and Portulaca oleracea L., with $0.5 \mathrm{mg} / \mathrm{ml}$ oil completely suppressed the seed germination of all the tested 


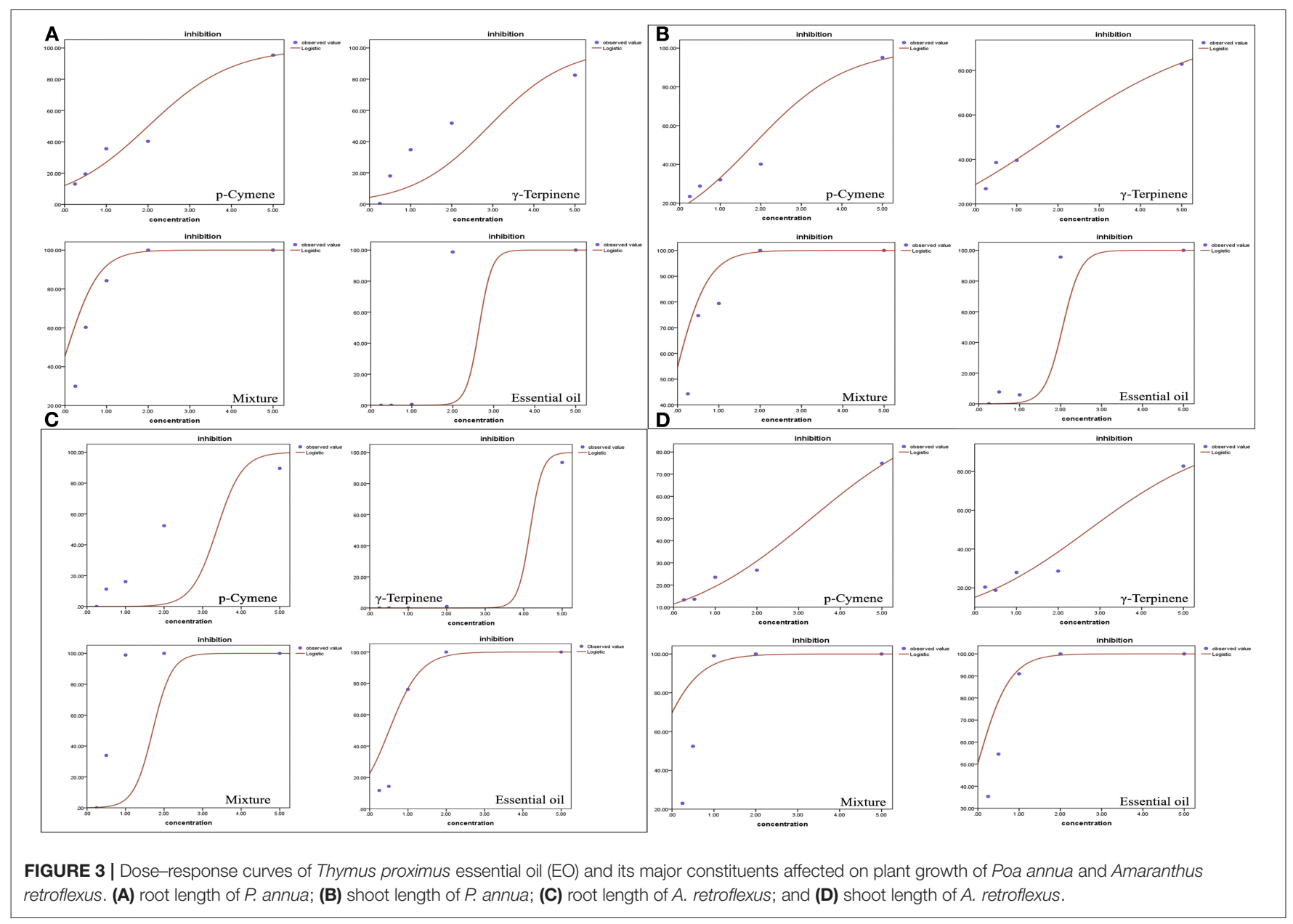

TABLE 3 | Toxicity of Thymus proximus essential oil (EO), p-cymene, $\gamma$-terpinene, carvacrol, and their mixture against Aphis gossypii adults.

\begin{tabular}{|c|c|c|c|c|}
\hline EO/major components & Regression equation & $r^{2}$ & $\mathrm{LC}_{50}(\mathrm{ppm})$ & $95 \% \mathrm{CL}$ \\
\hline EO & $y=0.053+3.202 x$ & 0.922 & 9.63 & $4.29-16.63$ \\
\hline p-Cymene & $y=0.95+3.882 x$ & 0.939 & 5.69 & $3.75-8.04$ \\
\hline$\gamma$-Terpinene & $y=0.729+4.348 x$ & 0.997 & 6.8 & $6.16-7.47$ \\
\hline Carvacrol & $y=1.94+0.963 x$ & 0.896 & 0.1 & $0.00-0.46$ \\
\hline Mixture & $y=0.398+2.79 x$ & 0.831 & 7.34 & $3.81-12.58$ \\
\hline
\end{tabular}

$r_{\text {adj }}^{2}$ : adjusted coefficient of determination.

$L C_{50}: 50 \%$ lethal concentration of $A$. gossypii.

95\% CL: 95\% confidence limits.

species (Zeynep et al.,, 2018). Sara et al. (2019) investigated the herbicidal action of $T$. fontanesii $\mathrm{EO}$ and found $0.03 \% \mathrm{~T}$. fontanesii oil inhibited the seed germination by 100\% on Sinapis arvensis, Avena fatua, Sonchus oleraceus, and Cyperus rotundus. In another study comparing the strength of phytotoxicity of 12 EOs produced by the Mediterranean aromatic plants conducted by Rolim et al. (2010), thyme, balm, vervain, and caraway EOs were found to be more active on germination and radicle elongation of receiver species; among them, thyme oil completely inhibited the seed germination of Lepidium sativum, Raphanus sativus L., and L. sativa at $1.25 \mu \mathrm{g} / \mathrm{ml}$. Synowiec et al. (2017) also performed a study comparing the phytotoxicity of 12 EOs and detected that T. vulgaris, Carum carvi L., Mentha piperita L., and Salvia officinalis L. oils possessed the most potent activity, with the $\mathrm{ED}_{50}$ values for thyme oil ranging between 0.06 and 1.03 $\mathrm{g} / \mathrm{L}$ against seven tested plants, which was comparable to our findings (Synowiec et al., 2017). Thymus pulegioides L. EO with high content of $\alpha$-terpinyl acetate inhibited the seed germination and radicle growth for high economic productivity forage grass monocotyledon Poa pratensis L (Vaiciulyte et al., 2021). Different extraction methods also cause differences in EO activity. Thymus decussatus EO extracted using hydrodistillation method inhibited 


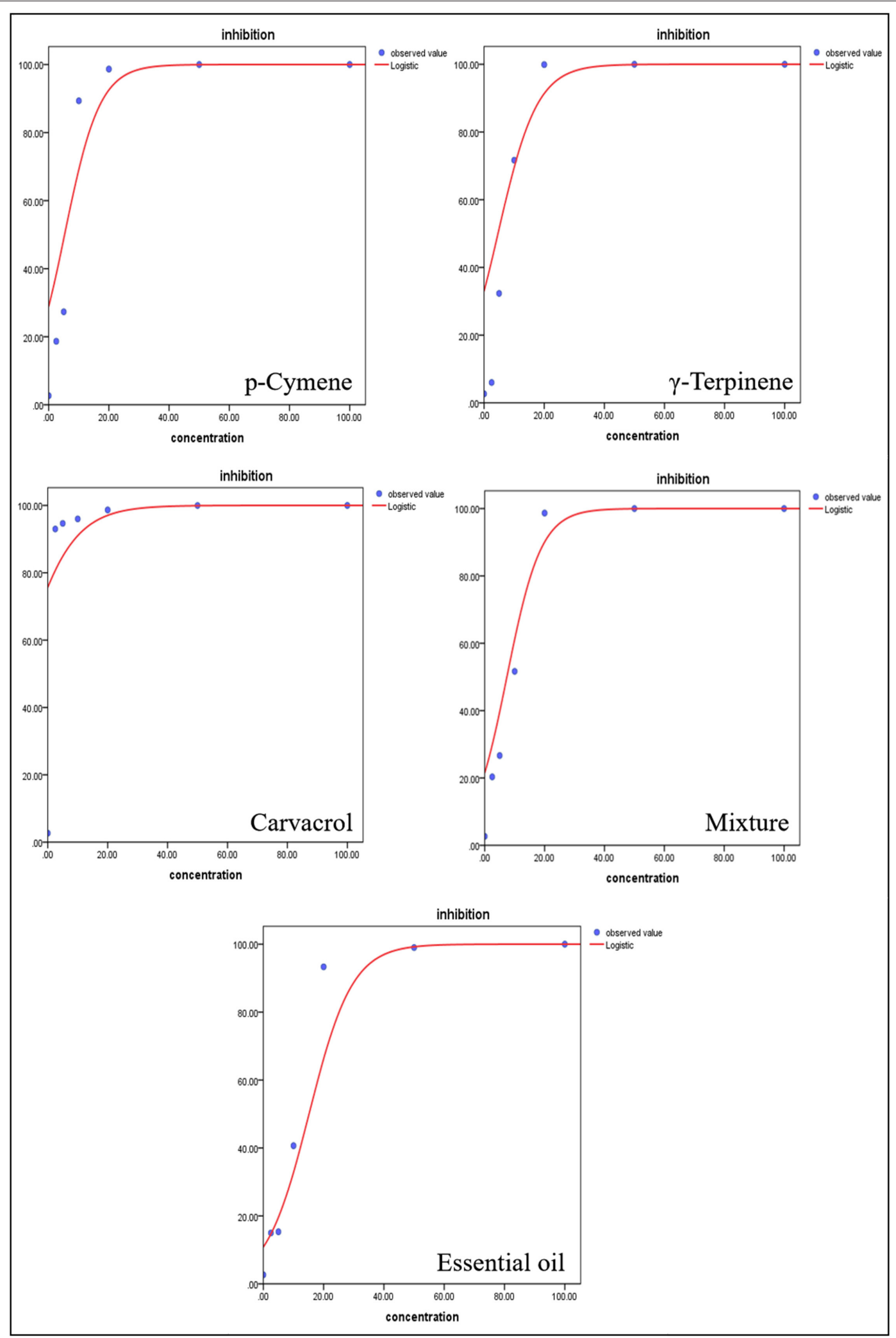

FIGURE 4 | Dose-response curves of Thymus proximus essential oil (EO) and its major constituents against Aphis gossypii adults. 
the seed germination, shoot growth, and root growth of lettuce by $86.6,87.4$, and $89.9 \%$, respectively, whereas the EO extracted using the microwave-assisted techniques method inhibited $L$. sativa by $77.7,85.8$, and $84.6 \%$ at $100 \mu \mathrm{l} / \mathrm{L}$, respectively (Saleh et al., 2020).

The phytotoxic effect of a particular EO can be mainly ascribed to certain toxic component(s). Monoterpene compounds have been reported to show strong inhibitory effects on the seed germination of many crops and weeds (López et al., 2008; Li et al., 2011; Ali et al., 2015). The outstanding phytotoxic activity of thymol has been previously studied. Thammyres et al. (2018) found that thymol exhibited phytotoxicity at different concentrations $(0.375-3 \mathrm{mmol} / \mathrm{L})$, as reflected on the reduced germination rate of tested monocot and dicot species. Kordali et al. (2008) found carvacrol and thymol prohibited the seed germination and seedling development of $A$. retroflexus, Chenopodium album, and Rumex crispus L., whereas p-cymene did not exert a significant phytotoxic activity $(8.6 \mathrm{mg} /$ Petri dishes). Consistent with this study, Vasilakoglou et al. (2013) reported thymol completely restrained the seed germination of rigid ryegrass (Lolium rigidum Gaudin) at $160 \mathrm{nl} / \mathrm{cm}^{3}$ or above, whereas p-cymene was found to be only slightly phytotoxic. Martino et al. (2010) tested the antigerminative activity of thymol, p-cymene, and $\gamma$-terpinene, along with other monoterpenes and found that thymol negatively affected the radicle elongation of garden cress significantly at $10^{-3} \mathrm{M}$, pcymene suppressed the root growth of garden cress at $10^{-4}$ $\mathrm{M}$; however, $\gamma$-terpinene did not exert any significant effect at tested concentrations. Meanwhile, the isomer of $\gamma$-terpinene, that is, $\alpha$-terpinene, was detected to be phytotoxic against maize seedlings by reducing the root growth, changing the root border cells number, increasing the pectin methyl esterase activity, and upregulating the repel expression in the roots (Wang et al., 2019). In conclusion, thymol exhibited much stronger phytotoxic activity compared with p-cymene and $\gamma$-terpinene, implying its role as the major active compound responsible for phytotoxicity of the oil.

Natural products with plant origin can play crucial roles in pest management practice (Faraone et al., 2015; Barua et al., 2020; Basaid et al., 2020; Chen and Oi, 2020). Previously, EOs synthesized by Thymus species have been demonstrated to possess insecticidal activity. T. serpyllum L. and T. vulgaris EOs presented a $\mathrm{LC}_{50}$ of $<10 \mathrm{mg} / \mathrm{dm}^{3}$ against the pest (Acanthoscelides obtectus say) of kidney bean (Phaseolus vulgaris L.) after $24 \mathrm{~h}$ of exposure (Regnault-Roger et al., 1993). Isman et al. (2001) tested 21 EOs for their insecticidal action via topical administration to third instar larvae of the tobacco cutworm, Spodoptera litura, and EOs of Satureja hortensis, Origanum creticum, and T. serpyllum exhibited over $90 \%$ larval mortality at $24 \mathrm{~h}$ at $100 \mu \mathrm{g} / \mathrm{larva}$; the $\mathrm{LD}_{50}$ value for S. hortensis (48.4 $\mu \mathrm{g})$ was comparable to that for T. vulgaris $(46.9 \mu \mathrm{g})$. Park et al. (2017) detected that the $\mathrm{LC}_{50}$ values of $T$. vulgaris $\mathrm{EO}$ against Pochazia shantungensis nymphs using the leaf dipping bioassay was recorded as 57.48 and $75.80 \mathrm{mg} / \mathrm{L}$ for adults using the spray bioassay method. Pavela (2005) tested the insecticidal activity of T. mastichina and T. vulgaris EOs against Spodoptera littoralis larvae and determined their $\mathrm{LD}_{50}$ values were 19.3 and $22.9 \mathrm{ml} / \mathrm{m}^{3}$. Thyme (T. vulgaris) EO was also found to show high activity against Lycoriella ingenua at $20 \times 10^{-3} \mathrm{mg} / \mathrm{ml}$ air (Park et al., 2008). EO produced by T. satureioides had moderate toxicity with the $\mathrm{LD}_{50}$ value of $0.31 \mu \mathrm{l} / \mathrm{cm}^{2}$ and the $\mathrm{LD}_{90}$ of $0.77 \mu \mathrm{l} / \mathrm{cm}^{2}$ against the important stored-product pest insect Tribolium castaneum (Kasrati et al., 2015). Ali et al. (2015) found the EOs obtained from all organs of T. algeriensis possessed strong insecticidal activity $\left(\mathrm{LC}_{50}=44.25-112.75 \mu \mathrm{l} / \mathrm{L}\right.$ air $)$ against cotton leafworm larvae (Spodoptera littoralis). In a recent study, EOs of T. spinulosus and T. longicaulis were assayed for their insecticidal toxicity, and their $\mathrm{LC}_{50} / \mathrm{LD}_{50}$ values were detected in the range of 39.6-87.1 $\mu \mathrm{g} / \mathrm{larva}, 21.7-62.4 \mu \mathrm{l} / \mathrm{L}$, and 35.9$147.3 \mu \mathrm{g} /$ adult, for Culex quinquefasciatus, Spodoptera littoralis, and Musca domestica, respectively; it is noteworthy to mention that they found the most active samples were those with the highest amounts of thymol (Pavela et al., 2019). A. gossypii were reported to be susceptible to a variety of EOs. For example, the strength of Santalum austrocaledonicum Vieill EO was comparable to imidacloprid (a neonicotinoid insecticide) against A. gossypii infesting Rose of Sharon (Hibiscus syriacus L.) with 98.8\% mortality (Roh et al., 2015). In another study, Melaleuca styphelioides Sm. EO exhibited strong fumigant toxicity on adults and nymphs of A. gossypii; $263.18 \mu \mathrm{l} / \mathrm{L}$ air EO let to $100 \%$ mortality of this insect (Albouchi et al., 2018).

Previous works have demonstrated the insecticidal activity of carvacrol, p-cymene, and $\gamma$-terpinene; in fact, carvacrol was speculated to be the main insecticidal compound of the EOs (Pavela and Sedlák, 2018; Pavela et al., 2019). Park et al. (2017) measured the insecticidal activity of thymol, carvacrol, citral, 2-isopropylphenol, 3-isopropylphenol, and 4isopropylphenol against Pochazia shantungensis adults, and their $\mathrm{LC}_{50}$ values were $28.52,56.74,89.12,71.41,82.49$, and 111.28 $\mathrm{mg} / \mathrm{L}$, respectively. Dias et al. (2019) evaluated the toxicity of thymol, cinnamaldehyde, carvacrol, eugenol, and trans-anethole on Mahanarva spectabilis eggs, nymphs, and adults, and they found that treatments with eugenol, carvacrol, and thymol showed the highest mortalities, presenting efficiencies higher than $85 \%$ after $48 \mathrm{~h}$ of application. Traboulsi et al. (2002) found that the compounds thymol, carvacrol, (1R)- $(+)-\alpha$-pinene, and (1S)-(-)- $\alpha$-pinene showed potent toxicity ( $\mathrm{LC}_{50} 36-49 \mathrm{mg} / \mathrm{L}$ ), whereas menthone, 1,8-cineole, linalool, and terpineol ( $\mathrm{LC}_{50}$ 156-194 mg/L) were less toxic to the mosquito Culex pipiens molestus. On the other hand, p-cymene and $\gamma$-terpinene also showed effective insecticidal activity. Cetin et al. (2010) detected that $\gamma$-terpinene triggered $\geq 90 \%$ knockdown against adult Hyalomma marginatum at $105 \mathrm{~min}$ through $3 \mathrm{~h}$, meanwhile at $24 \mathrm{~h}$ only about $87 \%$ of the ticks were dead. Another study found that both $\gamma$-terpinene and terpinen-4-ol exhibited a significant insecticidal effect on Spodoptera littoralis and $A$. fabae; however $\gamma$-terpinene was more toxic than terpinen-4-ol, with the $\mathrm{LC}_{50} / \mathrm{LD}_{50}$ values being $23.94 \mathrm{~g} / \mathrm{L}, 18.03 \mathrm{~g} / \mathrm{L}$ for $\gamma$ terpinene, and $32.94 \mathrm{~g} / \mathrm{L}, 20.77 \mathrm{~g} / \mathrm{L}$ for terpinen-4-ol, respectively (Abbassy et al., 2009). Silva et al. (2018) tested the activity of p-cymene and $\gamma$-terpinene against Rhipicephalus microplus and revealed their $\mathrm{LC}_{50}$ values were 1.41 and $3.08 \mathrm{mg} / \mathrm{ml}$, respectively. Tak and Isman (2017) tested the insecticidal activity of thymol, p-cymene, and their mixture against Trichoplusia $n i$, and the $\mathrm{LC}_{50}$ values were $244.3,875.4$, and $534.8 \mu \mathrm{g}$ /insect after $24 \mathrm{~h}$ of treatment, respectively; they also suggested that 
p-cymene seemed to enhance penetration of thymol through the integument. There was a study comparing the insecticidal activity of 11 Apiaceae plant EOs and their components on adult male and female Blattella germanica, and p-cymene and $\gamma$-terpinene were found to exhibit significant fumigant toxicity against adult Blattella germanica, whereas p-cymene exerted potent contact toxicity against adult Blattella germanica (Yeom et al., 2012). In the case of $T$. proximus EO, we discovered that the insecticidal activity of p-cymene, $\gamma$-terpinene, and the mixture of three major constituents was much weaker than carvacrol, which suggested that carvacrol might be the main responsible insecticidal compound in the oil. Moreover, these results supported the speculation that carvacrol was the major insecticidal compound of some EOs (Pavela and Sedlák, 2018; Pavela et al., 2019).

Among the three major constituents, carvacrol was found to possess much stronger biological activity compared with $\mathrm{p}$ cymene and $\gamma$-terpinene, although they are similar aromatic monoterpenoids. A recent study revealed that monoterpenoids can induce cell membrane dysfunction and interfere with cell metabolism, and $\mathrm{OH}^{-}$- and $\mathrm{O}^{-}$-radicals are considered to react with cellular components affecting homeostasis (Scariot et al., 2020). By comparing the chemical structures of carvacrol and p-cymene, it is speculated that the hydroxyl group of carvacrol might be critical for its potent activity. In another report, carvacrol was found to possess herbicidal activity due to its ability to incite membrane leakage (Chaimovitsh et al., 2017). On the other hand, it is noteworthy to mention that it is also possible that minor components in the oil might play important roles in the activity. Furthermore, due to the fact that EOs are composed of small molecules that can easily evaporate in the air, the optimization of the formula is necessary so as to stabilize the oils and their constituents.

\section{CONCLUSION}

Essential oils are valuable sources of providing candidate compounds as potential environment friendly pesticides and

\section{REFERENCES}

Abbassy, M. A., Abdelgaleil, S. A. M., and Rabie, R. Y. A. (2009). Insecticidal and synergistic effects of Majorana hortensis essential oil and some of its major constituents. Entomol. Exp. Appl. 131, 225-232. doi: 10.1111/j.1570-7458.2009.00854.x

Adebesin, F., Widhalm, J. R., Boachon, B., Lefevre, F., Pierman, B., Lynch, J. H., et al. (2017). Emission of volatile organic compounds from petunia flowers is facilitated by an ABC transporter. Science 356, 1386-1388. doi: 10.1126/science.aan0826

Ahmad, E., and Jaiswal, J. P. (2015). Inheritance of resistance to rice weevil (Sitophilus oryzae L.) in bread wheat (Triticum aestivum L.). Electron J. Plant Breed. 9, 1083-1093. doi: 10.5958/0975-928X.2018.00 135.7

Ahuja, N., Batish, D. R., Singh, H. P., and Kohli, R. K. (2015). Herbicidal activity of eugenol towards some grassy and broad-leaved weeds. J. Pestic. Sci. 88, 209-218. doi: 10.1007/s10340-014-0570-x

Albouchi, F., Ghazouani, N., Souissi, R., Abderrabba, M., and BoukhrisBouhachem, S. (2018). Aphidicidal activities of Melaleuca styphelioides Sm. herbicides, which can be utilized in pest and weed control safely due to their ability to degrade in nature, and the fact that they are less toxic to the environment. Our study is the first report on the allelopathic, phytotoxic, and pesticidal activities of the EO extracted from the aromatic plant $T$. proximus and on the determination of the major active compound, that is, carvacrol, to be responsible for the biological activity of the oil, implying their potential value of being explored as pesticides and herbicides. Limitations of our work include that only fumigant method was used to evaluate the insecticidal activity of T. proximus EO and its constituents against $A$. gossypii, and leaf dipping method needs to be performed in the future on more insects such as stored product pests.

\section{DATA AVAILABILITY STATEMENT}

The original contributions presented in the study are included in the article/supplementary material, further inquiries can be directed to the corresponding author/s.

\section{AUTHOR CONTRIBUTIONS}

SZ drafted the manuscript and wrote the manuscript. $\mathrm{CH}$ drew the scheme and edited the manuscript. CW performed the literature survey. CheZ performed the correction. NK edited and improved the scheme artwork. ChiZ and HS conceptualized, wrote, and edited the manuscript, and they performed the literature survey and ideation of the scheme. All authors contributed to the article and approved the submitted version.

\section{FUNDING}

This research was funded by the National Natural Science Foundation of China (U2003214), Regional collaborative innovation project of Xinjiang Uygur Autonomous Region (2019E01016), and the Taishan Scholars Program of Shandong, China (ts201712071). essential oils on three citrus aphids: Aphis gossypii Glover; Aphis spiraecola Patch and Myzus persicae (Sulzer). South Afric. J. Botany 117, 149-154. doi: 10.1016/j.sajb.2018.05.005

Alexa, E., Sumalan, R. M., Danciu, C., Obistioiu, D., Negrea, M., Poiana, M. A., et al. (2018). Synergistic antifungal, allelopatic and anti-proliferative potential of Salvia officinalis L., and Thymus vulgaris L. essential oils. Molecules. 23:185. doi: 10.3390/molecules23010185

Ali, I. B., Bahri, R., Chaouachi, M., Boussaid, M., and Harzallah-Skhiri, F. (2014). Phenolic content, antioxidant and allelopathic activities of various extracts of Thymus numidicus Poir. Organs. Industr. Crops Products 62, 188-195. doi: 10.1016/j.indcrop.2014.08.021

Ali, I. B., Chaouachi, M., Bahri, R., Chaieb, I., Boussaid, M., and Harzallah-Skhiri, F. (2015). Chemical composition and antioxidant, antibacterial, allelopathic and insecticidal activities of essential oil of Thymus algeriensis Boiss. et Reut. Industr. Crops Products 77, 631-639. doi: 10.1016/j.indcrop.2015.09.046

Aungtikun, J., Soonwera, M., and Sittichok, S. (2021). Insecticidal synergy of essential oils from Cymbopogon citratus (Stapf.), Myristica fragrans (Houtt.), and Illicium verum Hook. F. and their major active constituents. Industr. Crops Products 164:113386. doi: 10.1016/j.indcrop.2021.113386 
Barney, J. N., Sparks, J. P., Greenberg, J., Whitlow, T. H., and Guenther, A. (2009). Biogenic volatile organic compounds from an invasive species: Impacts on plant-plant interactions. Plant Ecol. 203, 195-205. doi: 10.1007/s11258-008-9529-4

Barua, A., McDonald-Howard, K. L., Donnell, R., Rae, R., and Williams, C. D. (2020). Toxicity of essential oils to slug parasitic and entomopathogenic nematodes. J. Pest Sci. 93, 1411-1419. doi: 10.1007/s10340-020-01251-5

Basaid, K., Chebli, B., Mayad, E. H., Furze, J. N., and Paulitz, T. (2020). Biological activities of essential oils and lipopeptides applied to control plant pests and diseases: a review. Int. J. Pest Manag. 67, 155-177. doi: 10.1080/09670874.2019.1707327

Behnaz, T., Mehdi, R., Ahmad, A., and Mohammad, R. S. (2020). Thymol, carvacrol, and antioxidant accumulation in Thymus species in response to different light spectra emitted by light-emitting diodes. Food Chem. 307:125521. doi: 10.1016/j.foodchem.2019.125521

Behnaz, T., Rahimmalek, M., and Arzani, A. (2017). Essential oil composition, total phenolic, flavonoid contents, and antioxidant activity of Thymus species collected from different regions of Iran. Food Chem. 220, 153-161. doi: 10.1016/j.foodchem.2016.09.203

Benhalima, H., Chaudhry, M. Q., Mills, K. A., and Price, N. R. (2004). Phosphine resistance in stored-product insects collected from various grain storage facilities in Morocco. J. Stored Prod. Res. 40, 241-249. doi: 10.1016/S0022-474X(03)00012-2

Cetin, H., Cilek, J. E., Oz, E., Aydin, L., and Yanikoglu, A. (2010). Acaricidal activity of Satureja thymbra L. essential oil and its major components, carvacrol and $\gamma$ terpinene against adult Hyalomma marginatum (acari: ixodidae). Vet. Parasitol. 170, 287-290. doi: 10.1016/j.vetpar.2010.02.031

Chaimovitsh, D., Shachter, A., Abu-Abied, M., Rubin, B., Sadot, E., and Dudai, N. (2017). Herbicidal activity of monoterpenes is associated with disruption of microtubule functionality and membrane integrity. Weed Sci. 65, 19-30. doi: 10.1614/WS-D-16-00044.1

Chandler, D., Bailey, A. S., Tatchell, G. M., Davidson, G., Greaves, J., and Grant, W. P. (2011). The development, regulation and use of biopesticides for integrated pest management. Philos. Trans. R. Soc., B 366, 1987-1998. doi: $10.1098 /$ rstb. 2010.0390

Chen, J., and Oi, D. H. (2020). Naturally occurring compounds/materials as alternatives to synthetic chemical insecticides for use in fire ant management. Insects 11:758. doi: 10.3390/insects11110758

Dias, M. L., Auad, A. M., Magno, M. C., Resende, T. T., Fonseca, M. G., and Silva, S. E. B. (2019). Insecticidal activity of compounds of plant origin on Mahanarva spectabilis (Hemiptera: Cercopidae). Insects 10:360. doi: $10.3390 /$ insects 10100360

Dudareva, N., Klempien, A., Muhlemann, J. K., and Kaplan, I. (2013). Biosynthesis, function and metabolic engineering of plant volatile organic compounds. $N$. Phytol. 198, 16-32. doi: 10.1111/nph.12145

Faraone, N., Hillier, N. K., and Cutler, G. C. (2015). Plant essential oils synergize and antagonize toxicity of different conventional insecticides against Myzus persicae (hemiptera: aphididae). PLoS ONE 10:e0127774. doi: 10.1371/journal.pone.0127774

Giunti, G., Campolo, O., Laudani, F., Zappal,à L., and Palmeri, V. (2021). Bioactivity of essential oil-based nano-biopesticides toward rhyzopertha dominica (coleoptera: bostrichidae). Industr. Crops Products 162:113257. doi: 10.1016/j.indcrop.2021.113257

Grayson, B. T., Williams, K. S., Freehauf, P. A., Pease, R. R., Ziesel, W. T., Sereno, R. L., et al. (1987). The physical and chemical properties of the herbicide cinmethylin (SD 95481). J. Pestic. Sci. 21, 143-153. doi: 10.1002/ps.2780210207

Han, C. X., Shao, H., Zhou, S. X., Mei, Y., Cheng, Z. R., Huang, L., et al. (2021). Chemical composition and phytotoxicity of essential oil from invasive plant, Ambrosia artemisiifolia L. Ecotoxicol. Environ. Safety 211:111879. doi: 10.1016/j.ecoenv.2020.111879

Hazzit, M., Baaliouamer, A., Faleiro, M. L., and Miguel, M. G. (2006). Composition of the essential oils of thymus and origanum species from algeria and their antioxidant and antimicrobial activities. J. Agric. Food Chem. 54, 6314-6321. doi: 10.1021/jf0606104

Imelouane, B., Amhamdi, H., Wathelet, J. P., Ankit, M., Khedid, K., and El Bachiri, A. (2009). Chemical composition and antimicrobial activity of essential oil of thyme (Thymus vulgaris) from Eastern Morocco. Int. J. Agric. Biol. 11, 205-208. doi: 10.1016/j.compag.2008.11.003
Inderjit, E. H., Crocoll, C., Bajpai, D., Kaur, R., Feng, Y. L., Callaway, R. M., et al. (2011). Volatile chemicals from leaf litter are associated with invasiveness of a Neotropical weed in Asia. Ecology 92, 316-324. doi: 10.1890/10-0400.1

Isman, M. B. (2015). A renaissance for botanical insecticides? Pest Manage. Sci. 71, 1587-1590. doi: $10.1002 /$ ps. 4088

Isman, M. B. (2017). Bridging the gap: moving botanical insecticides from the laboratory to the farm. Indust. Crops Prod. 110, 10-14. doi: 10.1016/j.indcrop.2017.07.012

Isman, M. B., Wan, A. J., and Passreiter, C. M. (2001). Insecticidal activity of essential oils to the tobacco cutworm, Spodoptera litura. Fitoterapia 72, 65-68. doi: 10.1016/S0367-326X(00)00253-7

Jia, H. L., Ji, Q. L., Xing, S. L., Zhang, P. H., Zhu, G. L., and Wang, X. H. (2010). Chemical composition and antioxidant, antimicrobial activities of the essential oils of Thymus marschallianus Will. and Thymus proximus Serg. J. Food Sci. 75, 59-65. doi: 10.1111/j.1750-3841.2009.01413.x

Kabouche, A., Kabouche, Z., and Bruneau, C. (2005). Analysis of the essential oil of Thymus numidicus (poiret) from Algeria. Flavour Frag. J. 20, 235-236. doi: $10.1002 / \mathrm{ffj} .1433$

Kang, G., Maryia, M., Kwame, S. A., Masaaki, Y., Akihito, T., Valery, P., et al. (2019). Screening for plant volatile emissions with allelopathic activity and the identification of L-fenchone and 1,8-cineole from star anise (Illicium verum) leaves. Plants 8:457. doi: 10.3390/plants8110457

Kashkooli, A. B., and Saharkhiz, M. J. (2014). Essential oil compositions and natural herbicide activity of four denaei thyme (Thymus daenensis celak.) ecotypes. J. Essent. Oil Bear. Plan. 17, 859-874. doi: 10.1080/0972060X.2014.884946

Kasrati, A., Alaoui, J. C., Bekkouche, K., Wohlmuth, H., Leach, D., and Abbad, A. (2015). Comparative evaluation of antioxidant and insecticidal properties of essential oils from five moroccan aromatic herbs. J. Food Sci. Technol. 52, 2312-2319. doi: 10.1007/s13197-014-1284-z

Kordali, S., Cakir, A., Ozer, H., Cakmakci, R., Kesdek, M., and Mete, E. (2008). Antifungal, phytotoxic and insecticidal properties of essential oil isolated from turkish Origanum acutidens and its three components, carvacrol, thymol and pcymene. Bioresour. Technol. 99, 8788-8795. doi: 10.1016/j.biortech.2008.04.048

Laborda, R., Manzano, I., Gamón, M., Gavidia, I., Pérez-Bermúdez, P., and Boluda, R. (2013). Effects of Rosmarinus officinalis and Salvia officinalis essential oils on Tetranychus urticae koch (acari: tetranychidae) Ind. Crop. Prod. 48, 106-110. doi: 10.1016/j.indcrop.2013.04.011

Langenheim, J. H. (1994). Higher plant terpenoids: a phytocentric overview of their ecological roles. J. Chem. Ecol. 20, 1223-1280. doi: 10.1007/BF02059809

Li, J., Liu, X., Dong, F., Xu, J., Li, Y., Shan, W., et al. (2011). Potential allelopathic effects of volatile oils from Descurainia sophia (L.) Webb ex Prantl on wheat. Biochem. Syst. Ecol. 39, 56-63. doi: 10.1016/j.bse.2010.12.022

López, M. L., Bonzani, N. E., and Zygadlo, J. A. (2008). Allelopathic potential of tagetes minuta terpenes by a chemical, anatomical and phytotoxic approach. Biochem. Syst. Ecol. 36, 882-890. doi: 10.1016/j.bse.2008.11.003

Majewska, E., Kozlowska, M., Gruczynska-Sekowska, E., Kowalska, D., and Tarnowska, K. (2019). Lemongrass (Cymbopogon citratus) essential oil: extraction, composition, bioactivity and uses for food preservation-a review. Pol. J. Food Nutr. Sci. 69, 327-341. doi: 10.31883/pjfns/113152

Marla, C. R., Herrera, A., Rosa, M., Martínez, S. J. A., and María, J. J. (2008). Antimicrobial activity and chemical composition of Thymus vulgaris, Thymus zygis and Thymus hyemalis essential oils. Food Control 19, 681-687. doi: 10.1016/j.foodcont.2007.07.007

Martino, L. D., Mancini, E., Almeida, L. F. R., and Feo, V. D. (2010). The antigerminative activity of twenty-seven monoterpenes, Molecules 15, 6630-6637. doi: 10.3390/molecules15096630

Nishida, N., Tamotsu, S., Nagata, N., Saito, C., and Sakai, A. (2005). Allelopathic effects of volatile monoterpenoids produced by Salvia leucophylla: inhibition of cell proliferation and DNA synthesis in the root apical meristem of Brassica campestris seedlings. J. Chem. Ecol. 31, 1187-1203. doi: 10.1007/s10886-005-4256-y

Oladipupo, L., and Adebola, O. (2009). Chemical composition of the essential oils of Cyperus rotundus L. from South Africa. Molecules 14, 2909-2917. doi: 10.3390/molecules14082909

Park, I. K., Kim, J. N., Lee, Y. S., Lee, S. G., Ahn, Y. J., and Shin, S. C. (2008). Toxicity of plant essential oils and their components against Lycoriella ingenua (diptera: sciaridae). J. Econ. Entomol. 101, 139-144 doi: 10.1093/jee/101.1.139 
Park, J. H., Jeon, Y. J., Lee, C. H., Chung, N., and Lee, H. S. (2017). Insecticidal toxicities of carvacrol and thymol derived from Thymus vulgaris $\mathrm{L}$. against Pochazia shantungensis chou \& lu. Newly recorded pest. Sci. Rep. 7:40902. doi: $10.1038 /$ srep 40902

Pavela, R. (2005). Insecticidal activity of some essential oils against larvae of Spodoptera littoralis. Fitoterapia 76, 691-696. doi: 10.1016/j.fitote.2005.06.001

Pavela, R. (2015). Essential oils for the development of eco-friendly mosquito larvicides: a review. Ind. Crops Prod. 76, 174-187. doi: 10.1016/j.indcrop.2015.06.050

Pavela, R., and Benelli, G. (2016). Essential oils as ecofriendly biopesticides? Challenges and constraints. Trends Plant Sci. 21, 1000-1007. doi: 10.1016/j.tplants.2016.10.005

Pavela, R., Fabrizio, B., Nicolas, D., Anne-Violette, L., Angelo, C., Filippo, M., et al. (2019). Chemical profiles and insecticidal efficacy of the essential oils from four Thymus taxa growing in central-southern Italy. Ind. Crops Prod. 138:111460. doi: $10.1016 /$ j.indcrop.2019.06.023

Pavela, R., and Sedlák, P. (2018). Post-application temperature as a factor influencing the insecticidal activity of essential oil from Thymus vulgaris. Ind. Crop. Prod. 113, 46-49. doi: 10.1016/j.indcrop.2018.01.021

Pichersky, E., and Gershenzon, J. (2002). The formation and function of plant volatiles: Perfumes for pollinator attraction and defense. Curr. Opin. Plant. Biol. 5, 237-243. doi: 10.1016/S1369-5266(02)00251-0

Pinto, Z. T., Sanchez, F. F., dos Santos, A. R., Amaral, A. C. F., Ferreira, J. L. P., Escalona-Arranz, J. C., et al. (2015). Chemical composition and insecticidal activity of Cymbopogon citratus essential oil from Cuba and Brazil against housefly. Rev. Bras. Parasitol. Vet. 24, 36-44. doi: 10.1590/S1984-29612015006

Raut, J. S., Karuppayil, S. M., Raut, J. S., and Karuppayil, S. M. A. (2014). Status review on the medicinal properties of essential oils. Ind. Crops Prod. 62, 250-264. doi: 10.1016/j.indcrop.2014.05.055

Regnault-Roger, C., Hamraoui, A., Holeman, M., Theron, E., and Pinel, R. (1993). Insecticidal effect of essential oils from mediterranean plants upon Acanthoscelides obtectus say (coleoptera, bruchidae), a pest of kidney bean (Phaseolus vulgaris L.). J. Chem. Ecol. 19, 1233-1244. doi: 10.1007/BF00987383

Roh, H. S., Kim, J., Shin, E. S., Lee, D. W., Choo, H., and Park, C. G. (2015). Bioactivity of sandalwood oil (Santalum austrocaledonicum) and its main components against the cotton aphid, Aphis gossypii. J. Pest Sci. 88, 621-627. doi: 10.1007/s10340-014-0631-1

Rolim, D. A. L., Fernando, F., Emilia, M., Laura, D. M., and Vincenzo, D. F. (2010). Phytotoxic activities of Mediterranean essential oils. Molecules 15, 4309-4323. doi: 10.3390/molecules 15064309

Ruther, J., and Kleier, S. (2005). Plant-plant signaling: Ethylene synergizes volatile emission in Zea mays induced by exposure to (Z)-3-hexen-1-ol. J. Chem. Ecol. 31, 2217-2222. doi: 10.1007/s10886-005-6413-8

Salamci, E., Kordali, S., Kotan, R., Cakir, A., and Kaja, Y. (2007). Chemical composition, antimicrobial and herbicidal effects of essential oils isolated Turkish Tanacetum aucheranum and Tanacetum chiliophyllum var. chiliophyllum. Biochem. Syst. Ecol. 35, 569-581. doi: 10.1016/j.bse.2007.03.012

Saleh, I., Abd-ElGawad, A., El Gendy, A. N., Aty, A. A., Mohamed, T., Kassem, H., et al. (2020). Phytotoxic and antimicrobial activities of Teucrium polium and Thymus decussatus essential oils extracted using hydrodistillation and microwave-assisted techniques. Plants 9:716. doi: 10.3390/plants9060716

Sanja, C. Z., and Milka, M. (2015). Chemical composition and bioactivity of essential oil from Thymus species in Balkan Peninsula. Phytochem. Rev. 14, 335-352. doi: 10.1007/s11101-014-9378-9

Sara, B., Mohamed, H., Nadjia, Z., and Hacène, A. (2019). Chemical composition and herbicidal activity of essential oils from two Labiatae species from Algeria. J. Essent. Oil Res. 31, 335-346. doi: 10.1080/10412905.2019.1567400

Scariot, F. J., Foresti, L., Delamare, A. P. L., and Echeverrigaray, A. P. L. S. (2020). Activity of monoterpenoids on the in vitro growth of two Colletotrichum species and the mode of action on C. acutatum. Pestic. Biochem. Phys. 170:104698. doi: 10.1016/j.pestbp.2020.104698

Shao, H., Hu, Y. X., Han, C. X., Wei, C. X., Zhou, S. X., Zhang, C. P., et al. (2018). Chemical composition and phytotoxic activity of Seriphidium terrae-albae (Asteraceae) essential oil. Chem. Biodiversity 15:e1800348. doi: $10.1002 /$ cbdv. 201800348

Silva, L. A., Milhomem, M. N., Santos, M. O., Arruda, A. C. P., Castro, J. A. M., and Fernandes, Y. M. L. (2018). Seasonal analysis and acaricidal activity of the thymol-type essential oil of Ocimum gratissimum and its major constituents against Rhipicephalus microplus (acari: ixodidae). Parasitol. Res. 117, 59-65. doi: 10.1007/s00436-017-5662-0

Sousa, R. M. O. F., Cunha, A. C., and Fernandes-Ferreira, M. (2021). The potential of Apiaceae species as sources of singular phytochemicals and plant-based pesticides. Phytochemistry. 187:112714. doi: 10.1016/j.phytochem.2021.112714

Stahl-Biskup, E., and Saez, F. (2002). Thyme. London: Taylor and Francis. doi: $10.4324 / 9780203216859$

Suteu, D., Rusu, L., Zaharia, C., Badeanu, M., and Daraban, G. M. (2020). Challenge of utilization vegetal extracts as natural plant protection products. Appl. Sci. 10:8913. doi: 10.3390/app10248913

Synowiec, A., Kalemba, D., Drozdek, E., and Bocianowski, J. (2017). Phytotoxic potential of essential oils from temperate climate plants against the germination of selected weeds and crops. J. Pest Sci. 90, 407-419. doi: 10.1007/s10340-016-0759-2

Tak, J. H., and Isman, M. B. (2017). Enhanced cuticular penetration as the mechanism of synergy for the major constituents of thyme essential oil in the cabbage looper, Trichoplusia ni. Ind. Crop. Prod. 101, 29-35. doi: $10.1016 /$ j.indcrop. 2017.03 .003

Tang, J. S., Jiang, C. Y., Liu, Y., Zhang, X. Y., Shao, H., and Zhang, C. (2019). Allelopathic potential of volatile organic compounds released by Xanthium sibiricum Patrin ex Widder. Allelopath. J. 47, 233-242. doi: 10.26651/allelo.j/2019-47-2-1234

Tanveer, A., Jabbar, M. K., Kahliq, A., Matloob, A., Abbas, R. N., and Javaid, M. M. (2012). Allelopathic effects of aqueous and organic fractions of Euphorbia dracunculoides Lam. on germination and seedling growth of chickpea and wheat. Chil. J. Agr. Res. 72, 495-501. doi: 10.4067/S0718-58392012000400006

Thammyres, A. A., Patrícia, F. P., Milene, M. P., Larissa, F. A., Kellen, B. C., Thayllon, A. A., et al. (2018). Toxicity of thymol, carvacrol and their respective phenoxyacetic acids in Lactuca sativa and Sorghum bicolor. Ind. Crop. Prod. 114, 59-67. doi: 10.1016/j.indcrop.2018.01.071

Traboulsi, A. F., Taoubi, K., Samih, E. H., Bessiere, J. M., and Rammal, S. (2002). Insecticidal properties of essential plant oils against the mosquito Culex pipiens molestus (diptera: culicidae). Pest Manag. Sci. 58, 491-495. doi: 10.1002/ps.486

Vaiciulyte, V., and Loziene, K. (2020). Impact of chemical polymorphism of Thymus pulegioides on some associated plant species under natural and laboratory conditions. Plant Biosystems. 154, 663-672. doi: 10.1080/11263504.2019.1674401

Vaiciulyte, V., Loziene, K., Svediene, J., Raudoniene, V., and Paskevicius, A. (2021). $\alpha$-Terpinyl acetate: occurrence in essential oils bearing Thymus pulegioides, phytotoxicity, and antimicrobial effects. Molecules 26:1065. doi: 10.3390/molecules 26041065

Vasilakoglou, I., Dhima, K., Paschalidis, K., and Ritzoulis, C. (2013). Herbicidal potential on Lolium rigidum of nineteen major essential oil components and their synergy. J. Essent. Oil Res. 25, 1-10. doi: 10.1080/10412905.2012. 751054

Vokou, D., Douvli, P., Blionis, G. J., and Halley, J. M. (2003). Effects of monoterpenoids, acting alone or in pairs, on seed germination and subsequent seedling growth. J. Chem. Ecol. 29, 2281-2301. doi: 10.1023/A:1026274430898

Wang, Y. N., Hu, Z. L., Hao, J. M., Qian, R. H., Ren, Q. R., and Ma, D. W. (2019). Allelopathic effects of volatile oil and its two main components from Chenopodium ambrosioides L. on maize (Zea mays) root border cells. Allelopath. J. 46, 215-228. doi: 10.26651/allelo.j/2019-46-2-1210

Wei, C. X., Zhou, S. X., Li, W. J., Jiang, C. Y., Yang, W., Han, C. X., et al. (2019). Chemical composition and allelopathic, phytotoxic and pesticidal activities of Atriplex cana LEDEB. (Amaranthaceae) essential oil. Chem. Biodivers. 16:e1800595. doi: 10.1002/cbdv.201800595

Williamson, G. B., and Richardson, D. (1988). Bioassays for allelopathy: measuring treatment responses with independent controls. J. Chem. Ecol. 14, 181-187. doi: 10.1007/BF01022540

Willmer, P. G., Nuttman, C. V., Raine, N. E., Stone, G. N., and Knudsen, J. T. (2009). Floral volatiles controlling ant behaviour. Funct. Ecol. 23, 888-900. doi: $10.1111 / j .1365-2435.2009 .01632 . x$

Wu, Z. Y., Li, X. W., Wang, W. C., Xuan S. J., Chen J., Huang S. Q., et al. (1983). Flora of China, Vol 66. Beijing: Science Press, 255.

Yang, Y., Isman, M. B., and Tak, J. H. (2020). Insecticidal activity of 28 essential oils and a commercial product containing Cinnamomum cassia Bark essential oil against Sitophilus zeamais Motschulsky. Insects 11:474. doi: $10.3390 /$ insects 11080474 
Yeom, H. J., Kang, J. S., Kim, G. H., and Park, I. K. (2012). Insecticidal and acetylcholine esterase inhibition activity of Apiaceae plant essential oils and their constituents against adults of German cockroach (Blattella germanica). J. Agric. Food Chem. 60, 7194-7203. doi: 10.1021/jf302009w

Zeynep U., Menderes C., Huseyin, I., and Murat, Y. (2018). Antimicrobial and herbicidal activities of the essential oil from the Mediterranean Thymus eigii, J. Essent. Oil Bear. Plants 21, 214-222. doi: 10.1080/0972060X.2017.1327824

Zhou, S. X., Wei, C. X., Zhang, C., Han, C. X., Nigora, K., and Shao, H. (2019). Chemical composition, phytotoxic, antimicrobial and insecticidal activity of the essential oils of Dracocephalum integrifolium. Toxins 11:598. doi: $10.3390 /$ toxins 11100598
Conflict of Interest: The authors declare that the research was conducted in the absence of any commercial or financial relationships that could be construed as a potential conflict of interest.

Copyright (c) 2021 Zhou, Han, Zhang, Kuchkarova, Wei, Zhang and Shao. This is an open-access article distributed under the terms of the Creative Commons Attribution License (CC BY). The use, distribution or reproduction in other forums is permitted, provided the original author(s) and the copyright owner(s) are credited and that the original publication in this journal is cited, in accordance with accepted academic practice. No use, distribution or reproduction is permitted which does not comply with these terms. 